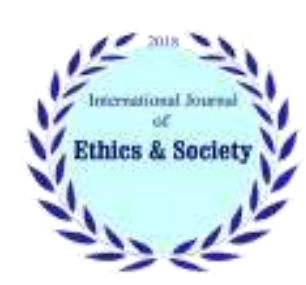

International Journal of Ethics \& Society (IJES)

Journal homepage: $\underline{\text { www.ijethics.com }}$

Vol. 2, No. 4 (2021)

(Review article)

\title{
Social \& Ethical Requisites of the Legal System to Enforce Foreign Judgments for Family Lawsuits
}

\author{
Farhad Afsharnia $^{a}$, Ali Ansari ${ }^{b *}$, Abdullah Kiaee ${ }^{c}$ \\ a) Ph.D. student in Private Law, Faculty of Humanities, UAE Branch, Islamic Aqad University, Dubai, UAE \\ b) Dept. of Private Law, Faculty of Humanities, University of Allameh Tabatabai, Tehran, Iran \\ c) Dept. of Private Law, Faculty of Humanities, Islamic Azad University, Zanjan, Iran
}

\begin{abstract}
Background: Identifying and enforcing the rulings and judgments on family lawsuits is so significant due to the relationship of many of them with public order and good domestic morality. Judges should regard factors such as the nationality of each of the litigants, their marital relationship, or their parental relationship in dealing with rulings in family litigation, in addition to applying a limited control system; this issue has been challenging in some cases; therefore, it is required to eliminate the ambiguity of the current laws and increase the judges' level of awareness on how to deal with such rulings and judgments. Consequently, this study was conducted in order to examine the social and moral requisites of the legal system to enforce family lawsuits.

Conclusion: Elements such as citizenship, marital residence, marital and parental relationship, and religion of the litigants play a significant role in identifying and enforcing family rulings in addition to the conditions specified in the Civil Code and laws related to the Civil Judgment Enforcement. Analyzes show that the legislature has caused significant ambiguities in this respect by delegating the enforcement of these rulings to the general enforcement of civil rulings, as well as the requirement for the judiciary to examine conflict resolution rules. Notwithstanding, the Family Protection Law of 2011, has examined only a very small dimension of the identification and implementation of these sentences only for the crime committed by the registrar without the presence of enforceable sentences.
\end{abstract}

Keywords: social, moral, family lawsuits.

\section{Introduction}

The significance of the family and its key role in preventing sexual perversions and social corruption

has been considered in today's world; therefore, maintaining the foundation of the family has been

* Corresponding Author: Email: ali.ansari1975@yahoo.fr

Received: 18 Jan 2021

Accepted: 16 Feb 2021 
regarded in the constitutions of countries and ordinary laws. In the Constitution of the Islamic Republic of Iran that its framework has been shaped based on Islamic religious law, the institution of the family has been considered in the introduction and two principles. The introduction of this law has considered the family as the fundamental unit of society and the main center of human growth and excellence, and Article 10 of the Constitution has stipulated that all laws, regulations, and plans must be arranged to facilitate the formation of the family, protect its holiness and strengthen family relations based on Islamic law. Article 21 of the same law has obliged the government to consider and implement measures to protect women's rights, including the establishment of a competent court to protect the integrity and durability of the family in the third paragraph of this principle.

Developing special laws and regulations related to family lawsuits and the faster implementation of rulings issued in this field need particular attention to this field's special procedure. Developing a specific procedure for family affairs and lawsuits that considers the moral and social obligations is one of the requirements of the family that should be respected; of course, this requirement has been considered to some degree by the judiciary in outlining the Family Protection Law; however, the changes made in this bill have caused it to diverge from its original objectives. Notwithstanding, family lawsuits are additionally subject to the general rules of civil procedure law, and this has resulted in disagreements in the interpretation and justification of laws, and additionally, the way that these judgments are enforced in the courts. Enforcement of judgments passed by domestic courts in the family lawsuit is double essential, as considered previously (1). Violating the laws and legal breaks in this field has resulted in the different procedure in terms of rulings issued by family courts, and this difference and dispersion of procedure have become more visible in the dimensions of rulings issued by foreign courts; because the need to go to foreign courts is inevitable by expanding the relations between countries and the presence and migration of third world countries to developed countries and the development of arguments between them, and the host countries investigate and issue rulings according to their government and law. These prerequisites sometimes contrast with the domestic law of individuals, and different mechanisms have been provided in domestic law and international treaties to get rid of this conflict; in such a way that it has shaped different systems to accept the foreign rulings of the family; as some countries realize foreign rulings to a limited degree and others accept them definitely (2). Realizing the foreign family rulings has been accepted in a restricted form in Iranian law; but in practice, some courts unconditionally refuse to accept these rulings, and since Iranian law is originated from the holy Islamic religious law, there are obstacles to enforce family rulings in Iran, and sometimes it is arranged without considering the moral and social standards, which must be recognized and taken some steps to eradicate them. Accordingly, in this article, it has been tried to examine the social and moral obligations of the ruling legal system in enforcing the foreign judgments of family lawsuits.

\section{Family Court}

Iranian law (Article 10 of the Constitution) has stipulated that all relevant laws, regulations, and plans must be based on Islamic law and morality to facilitate the formation of the family, protect its holiness and establish family relations. Clearly, not only the substantive rules but also the formal rules for supervising family lawsuits and the rules for enforcing the relevant rulings must have relevant logic and ethical principles in order to secure the interests of the family, which will be explained subsequently.

\section{Structure and competency of the family court in Iran}

Regarding that the judiciary has been obliged to establish a family court in Iranian law; accordingly, the first chapter of this law has been allocated to the "family court", and the related authority should be a special court with special inherent competency and jurisdiction, which will be reviewed in more detail subsequently. In Iran, the law on the establishment of a special civil court was approved on $7 / 8 / 1979$, according to which it was determined

2

Available at: www.ijethics.com 
that the special civil court would handle family lawsuits and disputes based on Islamic ethics and law. This law defined the jurisdiction of the court, the method of handling, the issuance of verdicts, and the appellate authority of the special civil court. The Special Civil Court was first set in Tehran and regularly in all cities, and operated for 15 years until the formation of the General and Revolutionary Courts on July 6,1994. Since then, family lawsuits have been examined under the jurisdiction of the general courts, and Paragraph 3 of Article 21 of the Constitution, the issue of setting a "competent court" to preserve the integrity and durability of the family, did not consider and examine. Dissatisfaction was emerged among the public due to the workload, the increase in the number of cases, and the length of proceedings caused by the inability of the judiciary to resolve disputes quickly and equitably during the years 1979-1994 when the special civil court administered the marital conflicts and family disputes. Disputes over the jurisdiction of special civil courts and legal and general courts of justice also caused the General Assembly of the Supreme Court to handle these disputes and issue a unanimous ruling to formulate a unified judicial procedure.

It can possibly be stated that none of the judicial authorities in the past was capable of completing the duty of a competent court to strengthen the family, preserve mothers and children, and revive the women's material and spiritual rights. Assigning this task to the general courts, which is the subject of the law on the establishment of general and revolutionary courts, produced more problems. The court examining and handling all kinds of crimes and private lawsuits and family lawsuits such as divorce, alimony, custody, etc. caused the judge to be incapable of calmly handling marital lawsuits and family disputes and trying to mediate between couples (3).

After eliminating the special civil courts, the judiciary did not take action to set a competent court to handle marital disputes and family conflicts; because the executives of this branch believed that the general court could better handle all legal, criminal, and family lawsuits and claims, and the concentration of different claims in one court will help speed up the processes; hence, The bill of the general court was submitted to the parliament without employing expert and scientific theories, regardless of some ethical and social criteria. The Judiciary and Legal Commission of the parliament did not pay attention to this bill's deficiencies and the problems resulting from its implementation. Also, no action was taken to implement this law, which should have been completed regularly over a period of 5 years, and the unavoidable decisions in the field of education and training of qualified judiciary were taken and implemented during this term, and the judiciary in the first and second years after its approval, implemented the law on general courts, which was called the "Law on the Establishment of General and Revolutionary Courts" in the parliament (4). The implementation of this law not only confused the judiciary; but also, delayed the trial. More importantly, marital litigation and family disputes, and other matters administered in special civil courts were obstructed between 1994 and 1997. At the same time, a plan proposed by more than 15 members of parliament to establish a competent court, the subject of Article 21 of the Constitution, was accepted by the general public, and the Singleclause Article of the law on allocating a number of branches of general courts to hear family lawsuits was approved by the Islamic Consultative Assembly on August 8, 1997, and it was approved by the Guardian Council on the 19th of the same month, and it was determined that a branch of the General Courts would be set up to handle family lawsuits.

\section{The current organizations of family court in Iran}

Today, Iranian family courts are formed in Tehran and other cities, and depending on the population, it can have one branch or more. The head of the judiciary determines the number of branches of the court. Court branches are normally located in one central location in cities with more than one branch and create a single jurisdiction called the Family Court Complex, or each branch is established in one part of the city. In Tehran, each branch of the family court has an alternate administrator or judge. Additionally, there is a female counselor with legal education and the position of judicial counsel in each branch of the family court, if possible. 


\section{The role of the female counsel judge}

Note 3 of single-clause Article 3 of the Law on the assignment of a number of courts to the courts of Article 21 of the Constitution, while establishing the legal institution of "female judicial counsel", specified that, "Every family court, as far as possible, will start to handle the cases with the presence of a female legal attorney, and verdicts will be issued after consultation with a female judicial counsel." But the mentioned regulation did not realize notable success; because, on the one hand, executing the sentence was not compulsory and was limited to "as much as possible", and on the other hand, the role of the female judicial attorney was solely to provide advice, without the judge of the court having any responsibility to do that. Hence, some experts criticized the mentioned regulation (5). Accordingly, the Family Protection Law in Iran has played a role both in assembling the trial meetings and in issuing the verdict in order to solve the stated problems for the female consultant judge and states that "the family court is held in the presence of the alternate administrator or judge and the female consultant judge." That is, the presence of a female consultant judge in the hearing is a condition for the formalization of the court. On the other hand, the consultant judge must insert a written and reasoned statement in the case on the subject matter of the lawsuit within three days from the end of the trial. The judge who drafts the verdict must refer to the opinion of the adviser judge in the lawsuit and, if he disagrees with it, deny his opinion by declaring the reason. Accordingly, the judge of the court in the position of drafting the verdict has no power and right to act without regarding the female advisor's opinion, but she must rationally reject her opinion even if her advisory opinion is not admitted.

\section{Jurisdiction of the Family Special Court in Iran}

Concerning the jurisdiction of the special family court, one of the aspects of the family court is the handling of lawsuits, complaints, and discussions that influence the consistency and stability of families. The legislature has handled certain matters to achieve this objective, that was earlier within the ju- risdiction of the special civil court, such as will/testamentary, wills, endowments, testamentary disposition up to one-third of the estate, imprisonment, trusteeship of other lawsuits with the consent of the parties, and handling the criminal lawsuits that have a direct connection with raised legal claims, has remained in the jurisdiction of the general courts and has been removed from the jurisdiction of the family special court. According to this fact that the family court is a special court and the special court does not hear and handle any case (except as permitted by law) and vice versa, the general court handles all cases and complaints (except cases that the law does not have jurisdiction on them). Accordingly, the jurisdiction of the family court is restricted to claims related to the following cases, which have been specified in the single clause Article of the law on the establishment of the family court:

1. Temporary and permanent marriage

2. Divorce

3. Dissolution of marriage

4. Dispense with the remaining term in temporary marriage and termination of the treaty

5. Dowry

6. Tocher

7. Fair equivalent remuneration and payments of marriage days

8. Delayed and current alimony of the wife and relatives of the obligatory alimony

9. Custody and visitation of children

10. Descent/genealogy

11. Unjustifiable disobedience of wife to husband and obedience of the wife to husband

12. Foundation of guardians and supervisors and trustees and their dismissal

13. Growth sentence

14. Remarriage

15. Conditions during the contract

16. Application for embryo donation according to the law on embryo donation approved in 2004 and its executive regulations.

The jurisdiction of the special family court is inherently competent to hear and handle these claims and complaints, and the jurisdiction of each court is determined by the same court; consequently, if the judge of the special family court determines that it has no inherent jurisdiction over the lawsuit, it

4

Available at: www.ijethics.com 
will issue an incompetence order directly and without any objection or notice from the defendant, and will refer the case to the competent and qualified authority.

\section{Theoretical concepts and foundations of the enforcement of the family law in Iranian law}

\section{- The concept of lawsuit}

The word "lawsuit" has two various meanings, one means to claim, want and demand, and the other means dispute and conflict (6). Accordingly, a lawsuit means claiming to be a plaintiff to become a self-righteous person, in other words, an action that is done in order to establish the right, and hence, any claim of the plaintiff and the defense of the plaintiff against which is brought in court is a legal lawsuit. Regarding the concept of family lawsuits, family lawsuits are commonly considered as nonfinancial and civil lawsuits.

\section{- The concept of execution of the sentence}

"Verdict/sentence" in legal terms, a court verdict is a verdict by which a dispute is settled in that court and the hostility finishes. It is stated in Iranian law (Article 299 of the Code of Civil Procedure), that "if the court's judgment on the nature of the lawsuit and its conclusive is partial or general, it is called a verdict/sentence, otherwise it is called an order." It should be remarked regarding the "types of sentences", that "sentences" are divided into concepts including judicial and administrative actions. Some have accepted this division and examined its effects. [7] According to some experts, "court ruling and verdict: from a legal perspective, the court decision that is made for a dispute is called a verdict that is a verdict or sentence whenever it is about the nature of the lawsuit and sometimes obstructs it; otherwise, it is deemed to be an order ..." (8) Another author believes: "the verdict of the court in its most comprehensive sense is the decision of the court that is made in adversarial matters or in nonlitigious matters or administrative matters; but the verdict, in its specific sense, is the decision of the court in adversarial matters ... "(9) It is also stated in another definition:" the decision of the courts is divided into judicial and administrative categories "(10). but the theory that is more appropriate to the subject matter is as follows: "On the one hand, we consider the word 'action' to explain the activity of a judge and consider its outcome instead of the right decision, and on the other hand, the division of court actions into judicial and administrative actions and "determining the criteria to identify each one is more theoretical." In fact, as has been announced, "identifying the decisions of the courts and their description and registration must be completed in order to examine the important implications that are related to each one" (11). Concerning the concept of enforcement, it should be stated; enforcement refers to the law or enforcement of the rulings of courts and tribunals or official documents (12) Enforcement in the legal and judicial sense is the exercise of public power to impose the provisions of a judicial authority sentence on a convicted person or to force a person to fulfill obligations and commitments which he or she has intentionally or under the authority of law. Normally, it is adequate for the judgment to be conclusive and binding for the court to enforce it in order to enforce a judgment issued by the domestic court of any country.

\section{The right to a lawyer in family litigation}

One of the issues that should be addressed when discussing family cases and lawsuits in family courts in Iran is the issue of advocacy. According to Article 32 of the Law of Iran, "in places where the Ministry of Justice announces, all or some of the legal claims, as well as claims against the verdicts and their defense in the courts, will be with the intervention of a lawyer. The Bar Association is required to provide a legal attorney for the poor or those who are incapable to pay the fee of attorney at the time of choosing a lawyer. "If after the announcement of the decision of the Ministry of Justice, the possibility of appointing an assistant lawyer in the place is limited due to the necessity of the lawyer's intervention or is not coordinated with the requirements of the place due to the increase in lawsuits, the Ministry of Justice can reject the implementation of that decision." (13) Regrettably, the sentence of this Article is one of the sentences that remained unenforced from the very start; what made the requirement for a lawyer in private lawsuits was 
a judgment that was forgotten after the victory of the Islamic Revolution. This situation lasted until 2005 that the Executive Regulations of Articles 31 and 32 of the Law Amending Some of the Laws of the Judiciary were approved on $5 / 2 / 2005$ by the Chief of the Judiciary and it was revised on 4/18/2005 and announced in circulars. According to the above-mentioned regulations, all lawsuits, including family lawsuits, could be registered and it was possible to defend it only with the intervention of a lawyer and in the presence of legal advisers, the subject of Article 187 of the Third Development Plan Law. The legislator does not specify the necessity of the presence of a lawyer in family affairs and lawsuits in the Family Protection Law and has stipulated only in the last part of Article 5 of this law: "... also if needed or there is a legal obligation "having a lawyer, the court, depending on the case, directly or at the request of a person without financial averages, designates a lawyer ...".

Execution of foreign judgments in family lawsuits and its socio-moral requisites

The first issue that the Iranian family courts should consider in identifying and enforcing foreign judgments is to recognize the nationality of the claimants and determine the law governing the lawsuit; because according to Articles 6 and 7 of the Iranian Civil Code, individuals' personal state is subject to the law of their respective governments. According to these Articles, "laws relating to personal sates such as marriage, divorce, and the competence of persons and inheritance should be applied to all Iranian citizens, even if they live abroad"; "Foreign nationals living in Iran will be subject to the laws and regulations of their respective governments within the limits of treaties in terms of their personal status and qualification, as well as in terms of inheritance rights." 'Two factors are usually considered in determining the law ruling personal states in the subject law of different countries;

1. First, the "residence" agent

2. Another one, "residence" (14)

Accordingly, If Iranians reside in countries whose domestic law does not apply the law of their respective governments to foreigners in subjects of the personal states, they can simply have the effects of the rulings issued in the same foreign country and cannot use the effects of those rulings that have been issued in violation of Iranian domestic regulations; preferably, they should refer to the courts of Iran and list a lawsuit in this regard (15) unless the domestic regulations of that country are similar in nature to those of Iranian regulations. It is required to explain that Iranian courts consider the observance of Iranian rules concerning the personal stats of Iranians living abroad in terms of substantive Iranian rules otherwise, according to Article 971 of the Civil Code of Iran, lawsuits in terms of the jurisdiction of the courts and the laws concerning the status of trials will be subject to the local law where they have been listed. Regarding the judicial procedure of Iranian courts, including family courts, these courts have been established that it enters into the nature of the dispute and handles the request for enforcement of divorce rulings in accordance with Iranian law in the situation of considering the request for enforcement of rulings issued by foreign courts, including divorce rulings, without issuing an enforcement order, and assumes the requested verdict as a statistic and an identical to their verdict, and issues a verdict after a substantive examination. (16) (according to Iranian law (Article 172 of the Civil Judgments Enforcement Law), the request to enforce the verdict requires the submission of a request, and payment of court fees is not enough and only a written request from the applicant is adequate. This request must be submitted to the court of the city of residence or habitation of the convicted person and if his place of residence or home is not known, it must be submitted to the court of Tehran. The court examines the request and documents in an extraordinary administrative session and, if the conditions are satisfied, issues an acceptance order to enforce the request and issues an order to execute it; in case of rejection of the request, the applicant can request that the verdict and order to be reconsidered within ten days from the date of notification of the provincial court of appeal (Article 175 of the Law on Enforcement of Civil Judgments); the latter court will additionally consider the matter in an extraordinary administrative session and, depending on the case, will termi-
6

Available at: www.ijethics.com 
nate the verdict under investigation, order the enforcement of the verdict or approve the mentioned verdict (Article 176 of the same law).

Of course, the cases discussed above were related to the differences among the couples in matters related to their personal states; but sometimes there are cases where the difference is related to the relationship between parents and children; whether it is first raised in an Iranian court or a verdict is presented to the Iranian courts for identification and enforcement. In this regard, if the citizenship of the parents and children is the same, the courts do not have a problem in recognizing the law governing the lawsuit, but sometimes in some lawsuits, the citizenship of the children and parents is different. The question is what law should be considered a ruling rule by the judge; the law of the parents' state or the law of the state of the children. Some believe that because the main objective should be to protect the interests of children in the relationship between parents and children, consequently, these relationships and lawsuits should also be considered subject to the law of the state of the children (14). On the other hand, others believe that in these relations, the parents are similarly beneficiary and since the father is the founder of the family and he is the leader of the family, the law of his respective state should be recognized as qualified (10). In its position of providing a solution in Article 964 of the Civil Code, the Iranian legislature has considered the law of the father's respective state to be qualified.

Another issue is the conflict between the guardian and the ward of the court, and a verdict on these individuals may be presented to the Iranian courts for identification and enforcement; it can be believed at the origin in such a hypothesis in order to determine the ruling law that the ruling on this issue is the same as the hypothesis of a dispute between parents and children; here, the law of the state of the guardian must also be considered the ruling law; because, the guardianship is additionally one of the relations between parents and children; but, contrary to this belief, it must be concluded that the objective of legal guardianship is to protect the minor, and it is assumed that the minor's respective state better provides his/her interests; accordingly, such a law should be considered in the dispute between the guardian and the ward of the court as the ruling law (14). This is the solution recognized by Article 965 of the Iranian Civil Code. The mentioned article has also raised the assumption of guardianship; according to this Article, it should be concluded that in the event of a dispute over issues related to the causes of guardianship, the administration of the property of the defendant, as well as the rights and duties of the guardian over the defendant, the law of the state of the defendant should prevail; however, the mentioned Article has only mentioned the foundation of a guardian. Some have discredited this inference and said: "It is undeniable that the intention of the legislator was not only to appoint a guardian, but also the relationship between the guardian and the ward of court against the duties of the guardian" (14)

Ultimately, regarding the method of preparing documents, it should be said that it is one of the exceptions to the rule of national law of Iran; because according to Article 969 of the Civil Code, "documents are subject to the law of the place of their arrangement" in terms of regulation. The purpose of the method of regulation is related to the form of the document and the purpose of the form is the external form which is related to the arrangement or construction of the document and not any form; like what language the contract should be written in. It has been said in justifying this case: such issues are related to the external form of the document and do not influence creating or destroying the rights of the parties to the contract (14). Consequently, a man and a woman who make a proper marriage abroad following the internal regulations of Iran, the manner of arranging the marriage contract and its registration, does not inevitably be following the regulations of Iran. Such a document is admitted in the courts of Iran in accordance with Article 1295 of the Civil Code (17). Another issue is that a document that has been prepared and validated abroad in accordance with Articles 969 and 1296 of the Civil Code, is considered valid only in terms of its external appearance and form; therefore, if the document is considered applicable abroad, it does not have such a description in Iran; hence, if such a document is expressed in a dispute 
between a couple, or if the subject matter of the ruling issued by a foreign court for identification and enforcement is related to such a document with such a declaration, it cannot be regarded enforceable; unless the Iranian court issues an order after its consideration; this is the related sentence as specified in Article 972 of the Civil Code.

In general, elements such as citizenship, the residence of the couple, marital and parental relationship, and religion of the parties play an important role in identifying and enforcing foreign judgments in family affairs, in addition to the conditions set out in the Civil Code and the Civil Judgments Enforcement Law. For example, at the time of dealing with a conflict of judgments, the Iranian judge explores the compliance of the judgments with the law ruling the matter from the perspective of the Iranian conflict resolution rules after qualifying as the executing judge and the jurisdiction of the court issuing the judgment. Interpretation of other rules of conflict resolution reaches the appropriate law.

\section{Conclusion}

This paper aimed to investigate the moral and social obligations of the ruling legal system in Iran in enforcing family lawsuits. First of all, concerning family rulings, according to the findings, it can be said that the Family Protection Laws approved in 1974 and 2012 and the Law on the Establishment of a Special Civil Court in 1979, have specified the requirement to observe court procedures in family matters and this has been specified in other laws. Notwithstanding, there has always been disagreement between the authors of the law of the country and the judges in determining the exact procedure of the trial and distinguishing it from the principles of the trial; in such a way that a coherent and comprehensive prospect in this regard cannot be achieved. Some experts present the criterion and consider the court proceedings as including the rules governing the procedure, and some consider the part of the trial that has no influence on the realization of the proceedings as a court formality. There are objections to each of these criteria. In any case, the principles of procedure should be considered as the foundations and institutions that govern the regulations and the legal materials deriving from them; These are fundamental principles that chart the concepts of total justice in resolving disputes, such as the principle of impartiality of the judge, the principle of openness of the trial, and the principle of preventing the issuance of contradicting opinions; however, despite the fact that court proceedings are also effective in the administration of justice, the degree of their influence on the verdicts is not like the basic principles of the proceedings and not observing them does not invalidate the verdict. Also, the principles of justice are derived from natural law, custom, reason, etc..; procedures, on the other hand, are rules that originated from legislative thought. Regrettably, the legislator's deficiency of clarification on what cases are court proceedings has raised many conflicts between the courts, and accordingly, it is better for the legislator to specify the court proceedings in order to prevent delays in the proceedings and to observe justice and the principles of the proceedings.

Concerning the system of enforcement of foreign judgments, it should be assumed that the enforcement of a sentence is a complicated establishment that on the one hand, requires specific and comprehensive legislation and on the other hand, has such intertwined dimensions that not all issues and details can be explained in the legislative field. This complexity is intensified when a judge is faced with identifying and enforcing judgments issued by foreign courts, particularly in family cases. The Iranian judge does not recognize well what to do with such judgments; on the one hand, the legislator has been satisfied to state some general and comprehensive regulations governing the identification and implementation of these rulings, and on the other hand, the courts of the country have not accepted a specific and established procedure in dealing with such judgments; Legal intellectuals have also considered the existing problems less in this field and have only sporadically explained some general governing principles; this necessitates the legislator's efforts to eliminate these ambiguities and weaknesses, the judge's research in 
the existing laws, and appeal to the principles governing the enforcement of such opinions and the doctrine's efforts to explain and demonstrate the principles and details governing this important issue. Accordingly, there are some proposals that are deserving of legal and judicial enforcement in order to promote justice and differential attention to the enforcement of foreign family judgments in Iran:

- Instruction judges the principles of conflict of laws in the field of enforcing family lawsuits;

- Amend the current regulations and explain special regulations in the field of enforcement of foreign family rulings;

- Legislation and extraction of judicial and practical findings in the enforcement of foreign judgments related to family affairs.

\section{Ethical Consideration}

Ethical issues (including plagiarism, informed consent, misconduct, data fabrication and/or falsification, double publication and/or submission, redundancy, etc.) have been completely observed by the authors.

\section{Acknowledgement}

Researchers consider it necessary to thank and appreciate all friends and faculty members who helped us in this research.

\section{References}

1. Ayatollahzadeh-Shirazi M, Azarnoush A, Adel M (2008). Dictionary. $5^{\text {th }}$ ed. Publication of Islamic Culture, Tehran/Iran. (In Persian).
2. Bodaghi F (2009). Family count procedure. $1^{\text {st }}$ ed. Mizan Publication, Tehran/Iran. (In Persian)

3. Rostami-Chelkasari A, Bazyar M (2016). Theory of cooperation between litigants and judges in resolving disputes. Journal of Law Researches, 7(1): 13. (In Persian).

4. Judiciary Training Deputy (2005). A set of advisory theories. $1^{\text {st }}$ ed. Javedaneh Publication, Tehran/Iran. (In Persian).

5. Safaee SH, Emami A (2014). Brief offamily law. $1^{\text {st }}$ ed. Mizan Publication, Tehran/Iran. (In Persian).

6. Moein M (2010). Persian dictionary. $2^{\text {nd }}$ ed. Behzad Publication, Tehran/Iran. (In Persian).

7. Katouzian N (2015). Ciwil law. $2^{\text {nd }}$ ed. Mizan Publication, Tehran/Iran. (In Persian).

8. Jafari-Langeroudi MJ (2016). Legal encyclopedia. 1st $^{\text {st }}$. Ganje Danesh Publication, Tehran/Iran. (In Persian).

9. Sadrzadeh-Afshar SM (2006). Evidence of litigation in Iranian law. 1st ed. University Publishing Center, Tehran/Iran. (In Persian).

10. Madani SJ (2011). Civil procedure. $1^{\text {st }}$ ed. Payedar Publication, Tehran/Iran. (In Persian).

11. Shams A (2016). Civil procedure. 1st ed. Derak Publication, Tehran/Iran. (In Persian).

12. Jafari-Langeroudi MJ (2016). Legal terminology. 1st ed. Ganje Danesh Publication, Tehran/Iran. (In Persian).

13. Mohajeri M (2011). Pathology of the new family support bill with emphasis on articles 8 to 16. Kanoon Monthy, 118. (In Persian).

14. Almasi NA (2016). Conflict of Laws. 1st ed. Center of University Publication, Tehran/Iran. (In Persian).

15. Yosefi M (2006). Iranians' referral to foreign courts. Tehran Family Excellence Monthly, 21. (In Persian).

16. Deputy of Justice Education of Tehran Province (2009). Judicial procedure of Tehran province counts of appeal in family affairs. $13^{\text {th }}$ vol. $1^{\text {st }}$ ed. Jangal Publication, Tehran/Iran. (In Persian).

17. Mirzaee A. (2010). Set of legal rules and regulations. $1^{\text {st }} \mathrm{ed}$. Behnami Publication, Tehran/Iran. (In Persian). 